症例報告

\title{
食道血管腫一症例報告と本邦報告例の検討
}

\begin{tabular}{|c|c|c|c|c|c|c|}
\hline \multicolumn{7}{|c|}{ 福岡大学筑紫病院外科 } \\
\hline 立石 & 訓己 & 有馬 & 純孝 & 二見喜太郎 & 立石 & 修三 \\
\hline 篠原 & 貫之 & 境田 & 隆二 & 兽根陽一郎 & 吉村 & 茂昭 \\
\hline 重田 & 正義 & 土器 & 潔 & 山崎 宏一 & & \\
\hline
\end{tabular}

\section{A CASE REPORT OF ESOPHAGEAL HEMANGIOMA} AND REVIEW OF LITERATURE

\author{
Satoshi TATEISHI*, Sumitaka ARIMA, Kitaro FUTAMI, \\ Shuzo TATEISHI, Tsurayuki SHINOHARA, Ryuji SAKAIDA, \\ Yoichiro SONE, Shigeaki YOSHIMURA, Masayoshi SIGETA, \\ Kiyoshi DOKI, Koichi YAMASAKI and Keiji TANAKA** \\ *Department of Surgery, Fukuoka University Chikushi Hospital \\ **Fukuoka Ishikai Seijinbyo Center Hospital
}

索引用語：食道血管腫による吐血

\section{I. 緒 言}

近年, $\mathrm{X}$ 線, 内視鏡診断技術の進歩により食道の微 細な病変も発見出来るよらになり, 食道良性腫痘の報 告例も増えているが，食道血管腫の報告は極めてまれ である。われわれは頸部食道に発生した血管腫の手術 例を経験したので，文献的考察を加えて報告する。

\section{II. 症例}

患者：52歳，女性.

主訴：吐血.

家族歴：特記すべきことなし。

既往歴：特記すべきことなし。

現病歴：昭和60年10月 3 日, 朝食後, 腹痛とともに 約 $200 \mathrm{ml}$ の吐血をきたし, 10 月 4 日近医へ入院. 食道造 影, 内視鏡検査で頸部食道に小隆起病変が認められた。 同年12月 4 日, 精査治療目的にて当科入院となった.

入院時所見：体格中等度, 栄養良好, 脈拍 $66 /$ 分, 血 压140/74mmHg, 貧血, 黄疸なし. 皮席, 粘膜の血管 腫は認めず，腹部は平坦で，肝，脾は触知しなかった。 検查所見: RBC : $425 \times 10^{4} / \mathrm{mm}^{3}, \mathrm{Hb} ; 12.2 \mathrm{~g} / \mathrm{dl}$

$<1989$ 年 3 月 8 日受理 $>$ 別刷請求先 : 二見喜太郎 T818 筑紫野市大字俗明院377-1 福岡大学筑紫病 院外科
Ht : $36.7 \%$, WBC : $6.200 / \mathrm{mm}^{3}$, Platlet : $23.9 \times 10^{4} /$ $\mathrm{mm}^{3}$. 肝機能, 電解質おょび堅機能異常なし.

胸部 X 線所見：異常所見なし.

食道造影所見：頸部食道前壁側に, 径 $5 \times 5 \mathrm{~mm}$ の辺 縁平滑な円形透亮像を認めた（図 1).

食道内視鏡所見：門雪列より約 $20 \mathrm{~cm}$, 前壁やや左 側に径 $5 \mathrm{~mm}$ の立ち上がり急峻な隆起性病変をみとめ た. その色調は発赤調で, 表面は正常の粘膜に覆われ, 潰瘍性病変，出血などはみられなかった，生検では vascular-rich granulation tissue の診断であった（図 2).

手術所見：食道血管腫の診断にて昭和 60 年 12 月 12 日, 全麻下に手術を施行した。皮膚切開は, 胸鎖乳突 筋の内側より鎖骨上縁までの斜切開. 頸部食道にテー ピング, 率引し, 同時に経口時に内視鏡を挿入して病 変を確認, 食道壁に約 $2 \mathrm{~cm}$ の緃切開を加え, 腫瘍を粘 膜下層, 粘膜とともに切除した（図 3 ).

摘出標本 : $5 \times 4 \times 2 \mathrm{~mm}$, 立ち上がり急峻, 境界鮮明 な隆起病変であり色調は発赤調, 表面平滑であった. 割面では表面を正常粘膜に覆われた淡褐色調の充実性 腫瘍であった（図 4 ).

組織学的所見：病变は粘膜下層に存在し,一㬝の内 
図 1 食道造影，頸部食道に円形陰影欠損

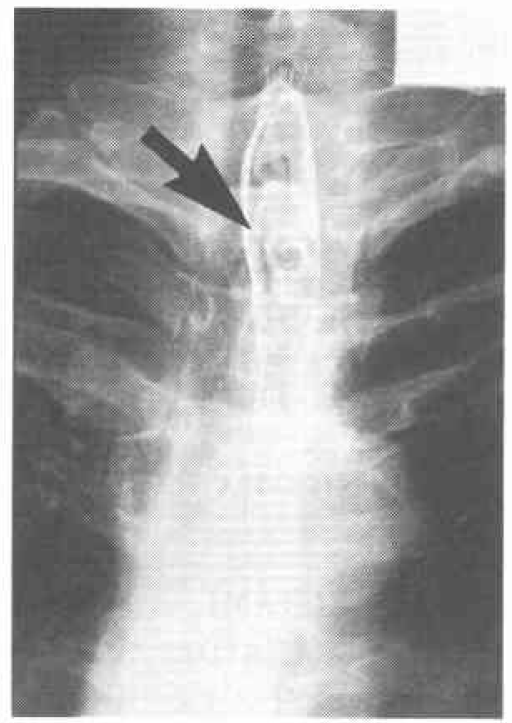

困 2 食道内視鏡，立ち上がり急峻な隆起性病変

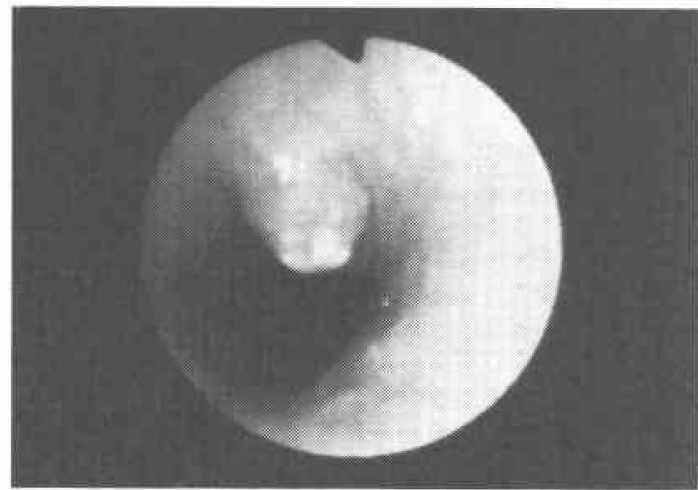

皮細胞よりなる小血管の増生がみられ毛細血管腫と診 断した（図 5).

\section{III. 考 察}

血管腫は一般に全身臓器に広く起こるものである が，とくに体表面に多く発生し，消化管に発生するる のは少なく, 頻度としては小腸, 大腸, 胃の順で, 食 道は極めてまれである。

食道に発生する良性腫場の頻度は Moersh ら ${ }^{1)}$ の剖 検資料によると， 7,549例中 44 例 $(0.6 \%)$, Plachta ${ }^{2}$ の それは 19,982 例中 90 例 $(0.5 \%)$ であった。いずれの報 告においても平滑筋腫が最も多く, Plachta ら”の報告 によると, 食道良性腫瘍 522 例中, 平滑笳腫 283 例 (54.2\%)，血管腫10例（1.9\%）である。
因 3 手術所見，頸部食道 (門茵より $20 \mathrm{~cm}$ ) に径 $5 \mathrm{~mm}$ の隆起病変

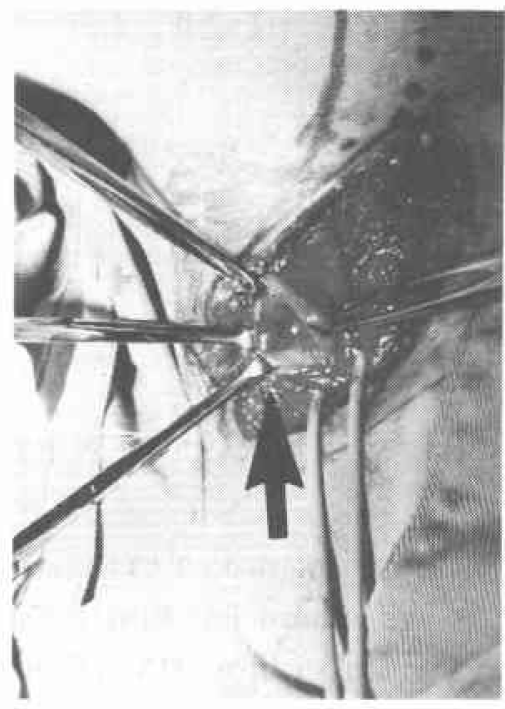

図 4 切除標本, $5 \times 4 \times 2 \mathrm{~mm}$ に境界明瞭な隆起病変

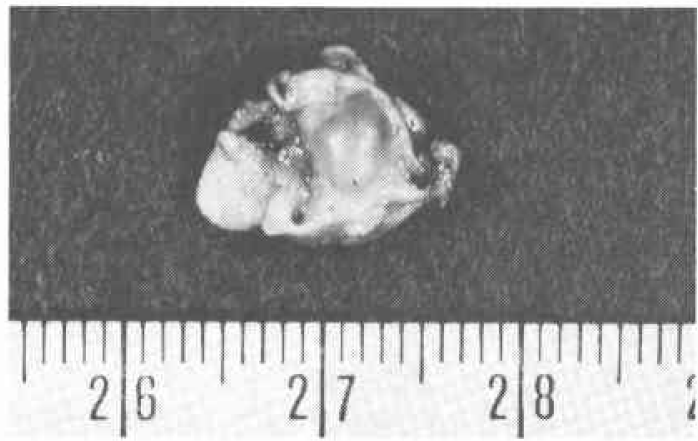

食道血管腫について最初の切除は, 1927年 Vinson ${ }^{4}$ によって施行されている．本邦では1951年中村ら ${ }^{8)}$ 報告以来，著者らが集計しえたところでは自験例もふ くめ42例(8) 28)である．本邦報告例によると年齢分布は 0 歳 82 歳までと幅広いが, 50 歳台が 12 人と最も多く， 次いで40歳台 7 人， 60 歳台 6 人であり，好発年齢は之 くに認められなかった，性別は不明の 3 例を除き，男 性24例，女性15例で，性差を認めていない，発生部位 は Riemenschneider ${ }^{5}$ とよると頸部 3 、胸部食道上部 1，中部 1 ，下部 2 と部位による差はないといわれて いる. 本邦報告例では食道入口部 3 例，頸部 4 例，胸 部食道上部 6 例, 中部10例, 下部14例, 胸部食道 1 例, 不明 4 例であり，中下部に存在する症例が約 $65 \%$ と多 い傾向がみられた。 
図 5 上段；組織所見 (ルーペ像).下段；組織所見， （強拡）一層の内皮細胞よりなる血管の増生

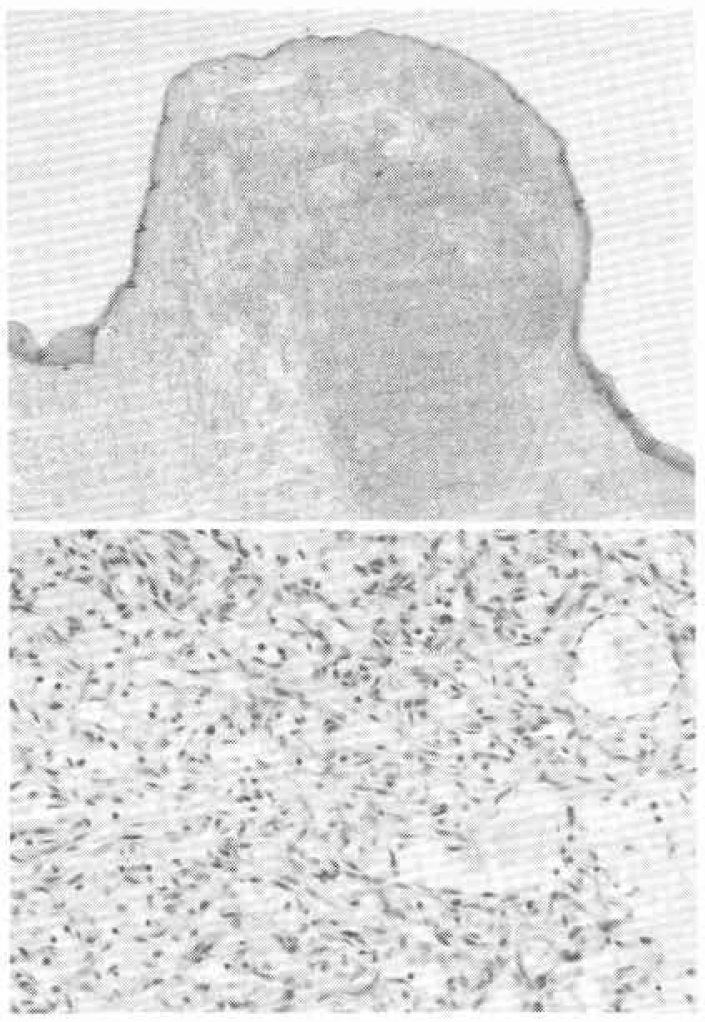

腫瘍の大きさは最大径でみると $5 \mathrm{~mm}$ から $170 \mathrm{~mm}$ ま で, 平均 $36 \mathrm{~mm}$ であった。

主訴は，曖下困難が34\%と多く，無症状26\%，吐下 血をきたした症例は11\%であった。 Hanel ら゙の報告 によると消化管出血 $41 \%$, 與下障害33\%, Govoni ${ }^{77}$ は消 化管出血 $28 \%$ ，曣下障害 $33 \%$ を認めており，この $2 つ$ が食道血管腫の 2 大症状と考えられる。

検査としては, 食道造影, 内視鏡が重要である。食 道造影の所見では, 腫瘤の形状は円形または卵円形の 陰影欠損を特徵とし，一般に潰瘍性病変は伴わず，造 影剂の病変部の通過は良好で, 口側の拡張もみられな いとされている、内視鏡所見は血管腫の診断には特に 重要である. 腫瘤の表面は正常食道粘膜で覆われてお り, 色調は青白調, 赤紫色調, 黄白色調を示すが色調 変化のないものもある.小口ら ${ }^{28)}$ は, 肉眼的所見と臨床 所見を比較の上，次の 3 群に分類している.

1 群; 腫瘤表面は青白色調から赤紫色調を呈し, そ の形態が山田のIまたはII型.
2 群；腫瘤表面は青白色調から赤紫色調を呈し，そ の形態が山田のIII型.

3 群；腫瘤表面は黄白色調または色調変化がないす ので，形態が山田のII 型またはIII型のもの.

術前に診断のついた19例（59\%）を調べてみるとそ の汪とんどが肉眼的所見によって診断が括こなわれて いる．また，同時にスコープの先端あるいは生検鉗子 による告迫で腫瘤が容易に陷凹することが重要な所見 となっており試みるべさである15).

生検に関しては, 従来は大出血の危険性があるため 禁忌とされていた。しかし，Palchick ら 29)は，51例の 血管腫のらち16例の生検を行い，また Hanel ら 例の血管腫集計で 9 例の生検を行い, いずれも全く出 血を認めなかったと報告し，診断の困難な症例につい ては，積極的に施行されるべきであると述べている. 自験例でも，生検にて食道血管腫疑いの診断を得てい るが，前述したように術前診断のついた19例は，その ほとんどが肉眼的所見によるものであり，特に生検の 必要はないと思われる。

本症は, 曣下困難や吐下血を認める症例はもとより, 大量出血を抗こす可能性があるので，たと無症状で も治療の対象となる。治療としては一般に，1.放射線 療法，2. 経鏡的摘出抢よび焼灼，3. 外科的摘出術が 行われている，皮膚などに発生した血管腫に対しては 放射線療法は有効であるが，食道などの場合，出血， 穿孔を起こす可能性があるため，最近では行われてい ない. $2 ， 3$ に関しては自験例のように頸部食道にあ る場合はそうでもないが，頻度としては中下部に多い ため，当然，腫瘤核出，摘出術を行らにも，開胸が必 要となり, 侵襲は大さくなる.小ロら 281 は, ポリペクト ミ一の適応を，スネアのかかる前述の分類の 2 群， 3 群に限定し, 出血, 穿孔の危険性が高いので慎重に行 ら必要があると述べているが，新井ら ${ }^{27}$ が述べるごと くパンェンドスコピーの普及により，表在型の小さい 血管腫の症例も増えており，今後本症における内視鏡 的ポリペクトミーの適応は増古ることが予想される.

\section{IV. 結 語}

頸部食道にみられた血管腫の 1 治験例を報告すると ともに，本邦報告例39例を集計し，若干の文献的考察 を行った。

な拈, 本論文の要旨は第28回消化器外科学会総会に打い て発表した。

\section{文献}

1) Moersh HJ, Harrington SW : Benign tumor of 
the esophagus. Ann Otal Rhnol Laryngol 53 : $800-817,1944$

2) Plachta A : Benign tumors of the wsophagus; review of literature and report of 99 cases. Am J Gastroenterol 38 : 639-652, 1962

3) Plachta A, Schmidt HW: Benign tumors and cysts of esophagus. J Thorac Cardiovasc Surg 41: 717-732, 1961

4) Vinson PP, Moore AB, Bowing $\mathrm{HH}$ : Hemangioma of the esophagus. Report of a case. Am J Med Sci $172: 416-418,1926$.

5) Riemenschneider HW, Klassen KP : Cavenous esophageal hemangioma. Ann Thorac Surg 6 : $552-556,1968$

6) Hanel K, Fracs, Talley NA et al: Hemangioma of the esophagus; An unusual case of upper gastrointestinal bleeding. Dig Dis Sci 26:257-263, 1981

7) Govoni AF : Hemangiomas of the esophagus. Gastrointest Radiol 7:113-117, 1982

8）中村四郎, 飯田信長：食道重複腫場の 1 例. 日気管 食道会報 $2 ： 35-36 ， 1951$

9）曾我基行, 大沢幹夫, 牛田 昇ほか：食道血管腫の 一治験例。臨外 $29: 419-422,1974$

10）山戸庸光, 浜中良郎, 橋本寿雄ほか：食道血管腫の 1 例。外科診療 $17: 635-638,1975$

11）川上寛子, 岡本昭二, 田辺義次㳗加：Rubber Bled Nevus Syndrome, 臨外 29:1043-1048, 1975

12）進藤勝久, 松尾康生, 桐林憲治ほか：食道曼状血管 腫手術の 1 例. 外科治療 $36: 621-624,1977$

13）金 正出, 鈴木元久, 城島標雄注か：食道粘膜下腫 瘍に対する診断法一食道壁層造影法の試み一。胃 と腸 $12: 663-668,1977$

14）北村道彦, 森 昌造, 渡辺登志男注 : 食道血管腫 の 1 治験例。臨外 $33: 1755-1759,1978$

15）綾部公唼, 中村 譲, 南 寛行はか：食道血管腫の 1 例. 日胸外会誌 $28: 1882-1887,1980$

16）藤原史郎, 岡本栄三, 桑田圭司柱か：食道血管腫の 1 治験例. 臨外 35：1613-1616, 1980
17）井田静雄, 正宗 研, 山本克夫注か：食道血管腫の 1 症例. 南大坂病医誌 $29: 28-32,1981$

18）高柳直己, 中田文輝, 千葉靖男注加: KasabachMerrit应候群の 2 例. 臨小医 $29: 339-344$, 1981

19）星加和德, 宮島宣夫, 藤村宣憲湫加：Blue rubber bleb nevus syndrome $の 1$ 例. Gastroenterol Endosc 25:453-457, 1983

20)正木久男, 藤原 魏, 土光荘六ほか：食道に発生し た Blue rubber-bleb nevus synd rome $の 1$ 例. 外 科 $45: 1473-1476,1983$

21）奥村輝久, 田上昭観, 千葉周伸任か：Lobular capillary hemangioma of the esophagus. A case report and review of the literature. Acta Pathol Jpn $33: 1303-1308,1983$

22）長崎雄二, 小林輝久, 藤井康広ほか：食道血管腫と 思われる病変に対する Aethoxysklerol 注入の 1 治験例. Prog Dig Endosc 24 ：206-208, 1984

23）倉下 隆, 林 隆一, 越川裕二ほか：内鏡的ポリへ クトミーを施行し得た食道血管腫の 1 例. Gastroenterol Endosc $27: 1882-1883,1985$

24）吉岡幸男, 酒井克治, 浜中良郎ほか：食道血管腫の 3 例. 消外 $8: 370-376,1985$

25）工藤正俊, 平佐昌弘, 高博任：内視鏡的ポリ ヘクトミーにて切除し得た食道血管腫の 1 例. Gastroenterol Endosc $28: 318-334,1986$

26）佐藤勝久, 浅木 茂, 小関弥平：内視鏡ポリペクト ミーしえた食道血管腫の 1 例. Prog Dig Endosc $28: 215-218,1986$

27）新井一成, 鈴木恵史, 谷尾 昇ほか：食道血管腫の 1 例. Prog Dig Endosc $29: 190-193,1986$

28）小口晋平, 鍋谷欣市, 小野沢君夫ほか：内視鏡的六 リペクトミーを施行した食道血管腫の 1 例一新し い臨床分類の試み一. Gastroenterol Endosc 29 : $96-100,1987$

29) Palchick BA, Alport MA, Holmes RA et al : Esophageal Hemangioma; Diagnosis with computed Tomography and Radionuclide Angiography. South Med J 76:1582-1584, 1983 